\title{
Validitas Kelompok Minat IImu Psikis-Tes Minat Indonesia dengan TPA dan Sikap Terhadap Pelajaran
}

\author{
Jelpa Periantalo, Edi Saputra, Freddi Sarman \\ Universitas Jambi, Indonesia \\ Jelp.8487@unja.ac.id
}

\begin{abstract}
The purpose of this research was to get the support of the validity of the Indonesian Interest Tests through the components of interest in Psychic Sciences with variables whose measurements were valid. Psychic Interest consisted of sub-interests in the fields of Theology, Philosophy, Psychology, Education, Children with Special Needs and Management. The validity test was carried out with Academic Potential Tests and Attitudes towards the Study. The subjects of this study were Jambi University FKIK new students who received a Psychology test at the beginning of registration. There was no relationship between Psychic Interest and TPA with $\rho x y=-0.076(p=0.1 I 4 ; p<0.05 ; N=$ 479). There was a positive relationship with the attitude towards Sociology subject $\rho x y=0.176(p=0.001 ; p<0.01$; $N=470)$, and negative with Biology $\rho_{x y}=-0.108(p=0.019 ; p<0.05 ; N=470)$ there was no connection with other subjects. The Indonesian Interest Test was supported by various information about the validity of the construct through variables whose measurements are valid so that it had the power to diagose individual interests. TMI could be used for high school specialization, college majors, self career development, learning material, and research. To strengthen the validity it is recommended to test with academic achievement and learning satisfaction in the Psychology study program.
\end{abstract}

Keywords: interests; psychic; constructs; spearman tho; validity

\begin{abstract}
Abstrak
Penelitan ini untuk mendapatkan dukungan validitas Tes Minat Indonesia melalui komponen minat Ilmu Psikis dengan variabel yang pengukuran sudah sahih. Minat Psikis terdiri dari sub minat di bidang Teologi, Filsafat, Psikologi, Pendidikan, Anak Berkebutuhan Khusus dan Manajemen. Uji validitias dilakukan dengan Tes Potensi Akademik dan Sikap terhadap Pelajaran. Subjek dari penelitian ini mahasiswa baru FKIK Universitas Jambi yang mendapatkan tes Psikologi diawal registrasi. Tidak ada hubungan antara Minat Psikis dengan TPA dengan $\varrho x y=-0,076(\mathrm{p}=0, \mathrm{II}$ I $; \mathrm{p}$ $<0,05 ; N=479)$. Terdapat hubungan positif dengan Sikap terhadap pelajaran Sosiologi $\varrho x y=0,176(p=0,00 I$; $\mathrm{p}<0,0 \mathrm{I} ; \mathrm{N}=470)$, dan negatif dengan Biologi $\mathrm{exy}=-0, \mathrm{IO} 8(\mathrm{p}=0,0 \mathrm{I} 9 ; \mathrm{p}<0,05 ; \mathrm{N}=470)$ tidak ada hubungan dengan pelajaran yang lain. Tes Minat Indonesia didukung berbagai informasi tentang validitas konstrak melalui variabel yang pengukuran sudah sahih sehingga memiliki kekuatan untuk mendiagosis minat individu. TMI dapat digunakan untuk peminatan SMA, penjurusan kuliah, penngembangan diri/karier, materi pembelajaran maupun penelitian. Untuk memperkuat validitas tersebut disarankan untuk uji dengan prestasi belajar maupun kepuasan belajar di program studi Psikologi.
\end{abstract}

Kata kunci: minat; psikis; konstrak; spearman rho; validitas 


\section{Pendahuluan}

Periantalo (2013, 20I4, 2015, 2016) menggunakan Tes Minat Indonesia dalam mendiagnosis minat seseorang, yang berfungsi memberikan rekomendasi peminatan SMA ataupun penjurusan kuliah. Tes Minat Indonesia dibuat didasarkan atas keterbatasan Tes Minat Kuder dan RMIB (Periantalo, 20II). Aspek yang ada di dalam alat tes tersebut sebanyak II/I2 aspek, sementara jurusan kuliah yang ada di Indonesia sangatlah beragam. Minat yang ada di dalam RMIB tidak bisa mengakomodir minat di jurusan kuliah, Tes Minat Indonesia pun mulai dibuat. Tes Minat Indonesia menggunakan pendekatan buttom up, aitem dibuat berasal dari kejadian yang ada di lapangan. Sumber pembuatan aitem berasal dari deskripsi program studi yanga ada di Indonesia. Terdapat beberapa kelompok keilmuwan, seperti: Ilmu Kesehatan, Ilmu Mesin, Ilmu Pertambangan, Ilmu Sosial, Ilmu Psikis. Pada kelompok Ilmu Psikis, terdapat minat Filsafat, Psikologi, Teologi, Pendidikan, Anak Berkebutuhan Khusus, Dunia Anak dan Manajemen

Syarat utama alat ukur yang baik adalah valid (Azwar, 2013, 20I4, 2017; Periantalo, 2015, 2016; Supratiknya, 20I4; Sumitro dan Widhiarso, 20I4). Validitas dikaitkan dengan tujuan utama dari alat ukur tersebut, apakah untuk kepentingan pembelajaran, diagnosis ataupun prognosis. Pada tujuan pembelajaran difokuskan pada validitas logis, sejauh mana alat ukur tersebut tercermin pada linearilitas antara tujuan instruksional pembelajaan, materi yang diajarkan serta soal. Alat ukur untuk tujuan diagnosis menitikberatkan pada validitas konstrak, sejauh mana konstrak tersebut mampu mecerminkan apa yang harus ditunjukkan dan tidak ditunjukkan melalui pengukuran tersebut. Pada tujuan prognosis, hal yang terpenting adalah sejauh mana alat ukur mampu memprediksi hal yang menjadi prekditor pada masa akan datang, seperti: prestasi belajar, prestasi kerja.

Tujuan utama dibuatnya Tes Minat Indonesia adalah untuk mendiagnosis minat seseorang siswa untuk peminatan SMA dan penjurusan kuliah. Hal tersebut berarti bahwa Tes Minat Indonesia harus memiliki banyak informasi mengenai validitas kontstraknya (Azwar, 20I4, 2015; Periantalo, 2015). Pada penelitian sebelumnya, informasi yang diberikan tentang TMI oleh berbagi uji validitas sudah memuaskan, tetapi perlu informasi baru untuk memperkuatnya. Terdapat hubungan positif minat ilmu kesehatan dengan Sikap terhadap Pelajaran Biologi (Periantalo, 20I4). Terdapat hubungan negatif antara Minat Ilmu Kesehatan dengan Minat Ilmu Psikis (Periantalo, 2017). Kelompok mahasiswa Psikologi memiliki minat bidang Psikis yang lebih tinggi dari mahaiswa ilmu kesehatan (Periantalo, 2018). Pada penelitian ini, penelitian menguji Tes Minat Indonesia dengan berbagai variabel lain, lebih banyak variabel daripada variabel sebelumnya, serta jumlah subjek yang lebih banyak.

\section{Metode}

\section{Jenis Penelitian}

Penelitian ini menggunakan pendekatan kuantitatif, yang berfokus menjelaskan fenomena berdasarkan skor (Azwar, 2017; Periantalo, 2015). Penelitian merupakan penelitian konstruksi alat ukur psikologi, berfokus mencapai validitas yang baik. Sejauh mana skor hasil pengukuran menunjukkan keadaan yang sebenarnya dari subjek yang dikenakan pengukuran. Penelitian ini merupakan penelitian yang berkontinu, terus menerus mengevaluasi properties psikometrisnya.

\section{Variabel Penelitian}

Variabel utama (X) dalam penelitian ini adalah Minat Psikis Tes Minat Indonesia. Minat diartikan sejauh mana kesenangan terhadap sesuatu objek, kegiatan atau pemikiran sehingga mendatangkan kepuasan bagi individu. Kelompok Minat Psikis TMI terdiri dari minat Filsafat, Psikologi, Manajemen, Anak Berkebutuhan Khusus, Pendidikan, dan Teologi. Variabel Y pertama adalah Tes Potensi Akademik, penalaran terhadap 
simbol verbal, angka dan abstrak. Variabel Y kedua yang menjadi kriteria adalah Sikap terhadap pelajaran sekolah, pandangan positif atau negatif terhadap pelajaran yang dipelajari di sekolah.

\section{Instrumen Penelitian}

Minat Ilmu Psikis TMI meggunakan Tes Minat Indonesia (Periantalo, 20I4; 2018). Tes tersebut dibuat untuk subjek remaja karena salah satu isunya adalah tentang pengembangan diri (Periantalo, 20II). Tes Potensi Akademik mengguakan TPA Universitas Jambi (Raudhah \& Periantalo, 2017). TPA memiliki koefisien reliabilitas internal $\alpha=0,87$ serta didukung berbagai validitas yang memuaskan. Skala sikap terhadap Pelajaran menggunakan teori Sikap dari Charles Osgood yang telah memiliki properties psikometris yang baik (Azwar, 20I2; Periantalo, 2016). Alat ukur tersebut memiliki validitas faktorial, reliabilitas dan kepraktisan yang baik. Validitas faktorial menunjukkan adanya koefisien faktor yang tinggi aitem dengan faktor terbentuk. Reliabilitas tes paralel skala Pelajaran Dasar menghasilkan koefisien ekivalensi rxx' Dasar rxx' $=0,93$ (Periantalo \& Fadzlul, 2016); Reliabilitas tes paralel untuk Skala Matematik dan Sains rxx' = 0,92 (Periantalo, Fadzlul, \& Saputra, 20I4) dan Skala Sosial Humanioa rxx' =0,93 (Periantalo, 2017).

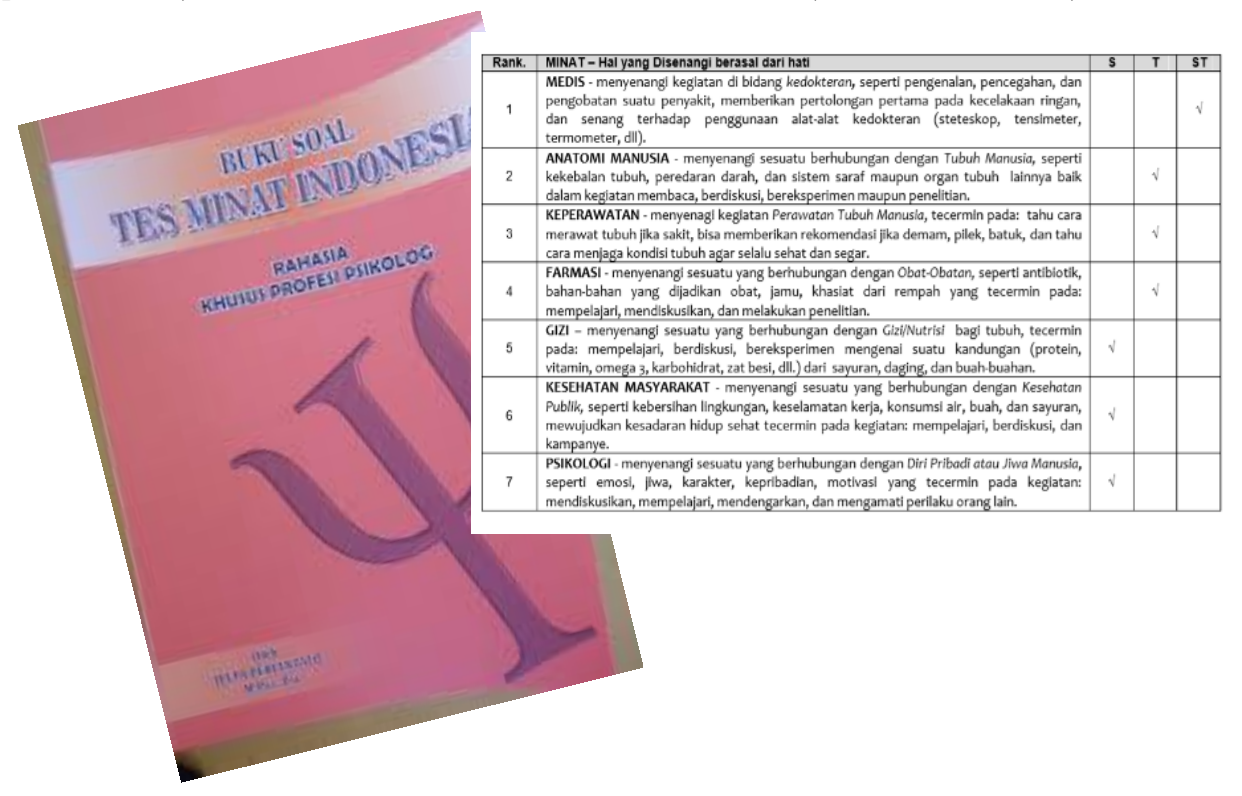

\section{Model Pemberian Skor}

TMI menggunakan konstrak ortogonal, hasil akhir dari alat tes tersebut berupa skor untuk masing-masing minat, bukan skor total pengukuran. Tes Minat Indonesia menggunakan pertanyaan dengan beberapa pilihan jawaban dengan ranking. Subjek diberi tujuh pilihan dari 99 pilihan jawaban, pilihan pertama mendapatkan skor 7, pilihan 2 mendapatka skor 6, pilihan terakhir mendapatkan skor I. Tes Potensi Akademik, dimana jawaban Benar=I dan Salah=0, skor maksimum 60 dan skor minimum 0. Pada skala Sikap terhadap pelajaran menggunakan semantif differensial, dua kata sifat yang bertolak belakang dengan rentang I-7.

\section{Subjek Penelitian}

Subjek dari penelitian ini adalah mahasiswa baru Fakultas Kedokteran dan Ilmu Kesehatan, Universitas Jambi angkatan 2015 dan 2016 (Periantalo dkk, 2015 \& 2016). Mahasiswa mendapatkan tes Psikologi diawali registrasi mahasiswa baru. Mahasiswa berasal dari Program Studi Kedokteran, Keperawatan, Kesehatan Masyarakat dan Psikologi. 


\section{Teknik Analisis Data}

Teknik analsisi dapat menggunakan bantuan software JASP 0.8.6.0 dari The University of Amsterdam, Belanda (Periantalo, 2017, 2018). Jeffrey's Amazing Statistical Program merupakan software yang open source (gratis), mudah dan sesuai dengan format APA. Pencipta/ketua tim adalah seorang Professor Metodologi Riset Psikologi. Teknik analisis menggunakan korelasi, hubungan di antara variabel. Sebelum dilakukan uji korelasi dilakukan uji asumsi terlebih dahulu. Apabila kedua data tersebut terdistribusi secara normal, Statistika Parametrik yang dilakukan; apabila tidak, Statistika nonparametric menjadi solusi.

\section{Hasil dan Pembahasan}

\section{Uji Validitas dengan Tes Potensi Akademik}

Uji validitas dengan Tes Potensi Akademik menggunakan skor mentah TPA secara keseluruhan dan berdasarkan komponen TPA. Terdapat empat analisis dalam data tersebut, uji dengan TVerbal, Kuantitatif, Abstrak dan TPA. Hipotesis dari uji ini adalah tidak ada hubungan antara Minat Psikis TMI dengan TPA sehingga memberikan dukungan minat Psikis. Dari tiga kompone TPA, Komponen Kuantitatif memiliki korelasi negatif, hal tersebut mengingat bahwa mahasiswa Psikologi kurang senang dengan operasi Hitungan (Periantalo, 2017).

Tabel I. Hasil Uji Korelasi Minat Psikis TMI dengan Tes Potensi Akademik

\begin{tabular}{lc}
\hline & TMI Minat Psikis \\
\hline Verbal & -0.035 \\
Kuantitatif & $-0.096^{* *}$ \\
Abstrak & -0.056 \\
TPA & -0.072 \\
\hline
\end{tabular}

$$
{ }^{*} \mathrm{p}>0.05 ;{ }^{2} \mathrm{p}>0.0 \mathrm{I} ; \mathrm{N}=479
$$

Hasil uji distribusi normal menunjukkan bahwa hanya TPA yang terdistribusi secara normal, variabel tidak terdistribusi secara normal korelasi Spearman Rho menjadi pilihan. Hasil uji korelasi menunjukkan bahwa tidak ada hubungan antara Minat Psikis TMI dengan TPA, Verbal dan Abstrak. Hal tersebut berarti bahwa informasi tentang Minat Psikis tidak dapat diketahui melalui kemampuan kognitif (TPA), Verbal maupun Abstrak. Terdapat hubungan dengan sangat lemah antara Minat Kesehatan dengan Kemampuan Kuantitatif dengan $\varrho x y=-0,096(p=0,036 ; p<0,05 ; \mathrm{N}=479)$. Hal tersebut menunjukan bahwa semakin tinggi minat Psikis seseorang, ada kemungkinan kemampuan kuantitatif semakin rendah.

\section{Uji Validitas dengan Skala Sikap terhadap Pelajaran}

Skala Sikap terhadap pelajaran terdiri dari tiga aitem yang mewakiliki setiap komponen dari Teori Minat Osgood. Pada Skala Sikap terhadap Matematika, komponen evaluasi diwakili oleh tidak bermanfaatbermanfaat, komponen aktivitas diwakili oleh membosankan-membetahkan, dan komponen potensi diwakili oleh rumit-sederhana. Terdapat I2 mata pelajaran sekolah yang diujikan dengan Tes Minat Indonesia. Hipotesis yang kuat diduga bahwa Pelajaran Sosiologi memiliki hubungan positif dengan Minat Psikis Tes Minat Indonesia. Hal tersebut didasari bahwa Psikologi mempelajari tentang manusia baik struktur internal maupun eksternal diri manusia, Sosiologi berkaitan dengan pola interaksi sosial di dalam masyarakat.

Tabel 2 Hasil Uji Minat Psikis TMI dengan Sikap terhadap Pelajaran Dasar

\begin{tabular}{lc}
\hline & TMI Minat Psikis \\
\hline Agama & 0.019 \\
Pkn & 0.031 \\
B. Indonesia & 0.125 \\
B. Inggris & 0.066 \\
\hline
\end{tabular}

$* \mathrm{p}>0.05 ; * * \mathrm{p}>0.01 ; \mathrm{N}=180$ 
Skala Sikap terhadap Pelajaran PKn terdistribusi secara normal, sementara yang lain Data terdistribusi tidak sehingga Korelasi Spearman Rho menjadi alternatif di dalam analisis data. Hasil uji korelasi dengan Skala Sikap terhadap pelajaran Dasar: Agama, PKn, Bahasa Indonesia dan Bahasa Inggris menunjukkan tidak ada hubungan dengan Minat Psikis TMI. Hal tersebut menunjukkan bahwa informasi mengenai Minat Psikis TMI tidak dapat diketahui dari Sikap terhadap Agama, Pkn, Bahasa Indonesia dan Bahasa Inggris.

Tabel 3. Hasil Uji Minat Psikis TMI dengan Sikap terhadap Matematika dan Sains

\begin{tabular}{lc}
\hline & TMI Minat Psikis \\
\hline Matematika & -0.070 \\
Fisika & -0.034 \\
Kimia & -0.061 \\
Biologi & $-0.108^{*}$ \\
\hline
\end{tabular}

Semua data terdistribusi secara tidak normal sehingga Korelasi Non Parametrik dapat ditegakkan, Spearman Rho dilakukan dalam analisis data. Hasil analisis menunjukkan bahwa tidak ada hubungan Minat Psikis TMI dengan Sikap terhadap pelajaran Matematika, Fisika dan Kimia. Hal tersebut menunjukkan bahwa informasi mengenai Minat Psikis TMI tidak dapat ditentukan dari Sikap terhadap Pelajaran Matematika, Fisika dan Kimia. Terdapat hubungan negatif sangat rendah Minat Psikis TMI dengan sikap terhadap Pelajaran Biologi $\varrho_{x y}=-0,108(\mathrm{p}=0,019 ; \mathrm{p}<0,05 ; \mathrm{N}=470)$. Hal tersebut menandakan bahwa semakin tinggi Minat Psikis seseorang, semakin rendah Sikap terhadap Pelajaran Biologi.

Tabel 4. Hasil Uji Minat Psikis TMI dengan Sikap terhadap Sosial Humaniora

\begin{tabular}{lc}
\hline & TMI Minat Psikis \\
\hline Ekonomi & 0.032 \\
Sosiologi & $0.176^{* *}$ \\
Sejarah & 0.033 \\
Geografi & 0.088 \\
\hline
\end{tabular}

$* \mathrm{p}>0.05 ; * * \mathrm{p}>0.01 ; \mathrm{N}=180$

Hasil uji Normalitas menunjukan bahwa data tidak terdistribusi secara normal, Korelasi dilakukan dengan korelasi Spearman Rho. Hasil uji korelasi menunjukkan bahwa terdapat hubungan positif sangat rendah antara Minat Psikis TMI dengan Sikap terhadap Pelajaran Sosiologi $\varrho x y=0,176(p=0,036 ; p<0,05$; $\mathrm{N}=470$ ). Hal tersebut menunjukkan bahwa semakin tinggi Minat Psikis TMI, semakin positif sikap terhadap pelajaran Sosiologi. Siswa yang memiliki pandangan positif terhadap pelajaran Sosiologi, ada kemungkinan ia menyenangi sesuatu yang berhubungan dengan diri dan pribadi manusia. Tidak terdapat hubungan antara Minat Psikis TMI dengan Sikap terhadap Pelajaran Ekonomi, Sejarah dan Geograpi. Hal tersebut menandakan bahwa informasi mengenai Minat Psikis, tidak dapat diketahui melalui Sikap terhadap Ekonomi, Sejarah maupun Geograpi.

\section{Penutup}

Terdapat hubungan positif antara Komponen Minat Psikis Tes Minat Indonesia dengan skala sikap terhadap pelajaran Sosiologi. Terdapat hubungan negatif dengan Penalaran Verbal dan Sikap terhadap Pelajaran Biologi. Dukungan validitas ini memperkuat kesahihan Tes Minat Indonesia sehingga layak dalam memberikan gambaran minat seseorang. Untuk keperluan diagnosis, TMI sudah dapat dipercaya hasilnya dengan baik. Penelitian berikutnya disarankan untuk melakukan uji validitas dengan prestasi belajar, lama studi maupun kepuasan belajar pada mahasiswa Psikologi. Hasil tersebut dapat dijadikan landasan untuk menjadikan sebagai alat ukur prediksi, seleksi atau prognosis. 


\section{Daftar Pustaka}

Azwar, S. (2013). Reliabilitas dan validitas. Pustaka Pelajar: Yogyakarta.

Azwar, S. (2014). Sikap manusia: Teori dan pengukurannya. Pustaka Pelajar: Yogyakarta.

Azwar, S. (20I4). Penyusunan skala psikologi. Ed. Ke-2. Pustaka Pelajar: Yogyakarta.

Azwar, S. (20I4). Konstruksi tes kognitif. Pustaka Pelajar: Yogyakarta.

Azwar, S. (2016). Dasar-dasar psikometri. Ed. Ke-2. Pustaka Pelajar: Yogyakarta.

Azwar, S. (2017). Metode penelitian psikologi. Ed. Ke-2. Pustaka Pelajar: Yogyakarta.

Periantalo, J. (20I I). Laporan praktek kerja profesi psikologi tingkat SMAN 9 Yogyakarta. (Laporan praktik tidak dipublikasikan). Fakultas Psikologi Universitas Gadjah Mada, Yogayakarta.

Periantalo, J. (20I I). Laporan praktek kerja profesi psikologi tingkat SMPN 5 Yogyakarta. (Laporan tidak dipublikasikan). Fakultas Psikologi Universitas Gadjah Mada, Yogayakarta.

Periantalo, J., dkk. (2013, 2014, 2015, 2016). Laporan Tes Psikologi untuk Penjurusan Kuliah. Good and Great Consultant, Jambi.

Periantalo, J., dkk. (2013, 2014 2015, 2016). Laporan Tes Psikologi Seleksi Mahasiswa Baru. Fakultas Kedokteran dan Ilmu Kesehatan Universitas Jambi. Universitas Jambi, Jambi.

Periantalo, J. (20I4, Desember). Penyusunan tes minat Indonesia sebagai upaya pengembangan diri generasi muda Indonesia. Presented at Temu Ilmiah Nasional 20I4 Fakultas Psikologi Universitas Airlangga, Surabaya.

Periantalo, J., Fadzlul \& Saputra, N. E. (20I4). Konstruksi skala sikap terhadap pelajaran Matematika dan Sains. Jurnal Edu Sains Universitas Jambi 3 (2), 36-45.

Periantalo, J. (2015). Penyusunan skala psikologi: asyik, mudah dan bermanfaat. Pustaka Pelajar: Yogyakarta.

Periantalo, J. (2015). Validitas alat ukur psikologi: Applikasi praktis. Yogykarta: Pustaka Pelajar.

Periantalo, J. \& Fadzlul (2016). Penyusunan skala sikap terhadap pelajaran dasar sebagai upaya optimalisasi pembelajaran. Jurnal Penelitian Universitas Jambi Seri Sosial Humaniora, I8 (2), 23-33.

Periantalo, J. (2016). Penelitian Kuantitatif untuk Psikologi. Yogyakarta: Pustaka Pelajar.

Periantalo, J. (2017). Statistika Dasar untuk Psikologi: Yogykarta: Pustaka Pelajar.

Periantalo, J. (2018). Softaware Statistika untuk Psikologi: JASP Free, Flexible. Yogyakarta: Pustaka Pelajar.

Periantalo, J. (2017). Propertis Psikometris Skala Sikap Terhadap Pelajaran Sosial Humaniora. Jurnal Ilmu Perilaku I (2), 98-I09.

Periantalo, J. (20I7). Uji validitas konstrak Tes Minat Indonesia melalui aspek minat ilmu psikis. Psycho Idea I5 (I), 9-I7.

Periantalo, J. (2018). Uji validitas konstrak Tes Minat Indonesia melalui komponen minat kesehatan. Psycho Idea I6 (I), 39-50.

Supratiknya, A. (20I4). Pengukuran psikologis. Yogyakarta: Penerbit Universitas Sanata Darma. 